\title{
ע Toimeentulotuen saajien lääkekorvausoikeudet ja lääkkeiden käyttö
}

Eriarvoisuus terveyspalvelujen laadussa ja saatavuudessa voi vahvistaa sosioekonomisia terveyseroja. Toimeentulotuen saajat sairastavat ja käyttävät julkisia terveyspalveluja muuta saman ikäistä väestöä enemmän. Tutkimuksessa vertailtiin rekisteriaineiston avulla toimeentulotuen saajien $(N=37$ 836) ja ei-toimeentulotuen saajien ( $N=430$ 997) lääkekorvausoikeuksia ja lääkkeiden käyttöä Helsingissä vuonna 2010. Menetelminä käytettiin vakiointia ja logistista regressioanalyysia. Kun erot ikä- ja sukupuolirakenteessa, maahanmuuttajataustassa, tulotasossa ja opiskelijoiden osuudessa vakioidaan, toimeentulotuen saajilla on ei-toimeentulotuen saajia useammin lääkekorvausoikeuksia (20\% vs. $15 \%$ ) sekä psyykensairauksiin (34\% vs. $14 \%$ ), astmaattisiin sairauksiin (11\% vs. $5 \%$ ), diabetekseen (6\% vs. $3 \%$ ) ja sydän- ja verisuonisairauksiin (21\% vs. $13 \%$ ) liittyviä lääkeostoja. Psyykenlääkkeiden käyttö yleistyy toimeentulotuen saantikuukausien määrän kasvaessa, mutta psyyken sairauden vuoksi erityiskorvaukseen oikeutetut saavat toimeentulotukea yleisimmin vain muutaman kuukauden. Psyykenlääkityksen (korvausoikeus tai lääkeosto) ja toimeentulotuen saannin yhteys on samansuuntainen kantaväestöllä ja maahanmuuttajilla (toimeentulotukea $\mathrm{I}-3$ kuukautta ja 10-12 kuukautta saaneilla ristitulosuhteet (OR) 2,8 [2,7-2,9] ja 5,3 [5,0-5,5] kantaväestöllä; 2,4 [I,9-3,2] ja 7,8 [6,4-9,5] OECD-maista saapuneilla; 2,3 [I,8-3,0] ja 3,6 [2,9-4,3] entisen Neuvostoliiton alueelta saapuneilla; ja 2,0 [I,6-2,6] ja 5,I [4,4-6,0] muista kuin em. maista saapuneilla, kun vertailuryhmänä ei-toimeentulotuen saajat). Tutkimus vahvistaa käsitystä sairaudesta osana huono-osaisuutta. Terveysongelmien yleisyys on syytä ottaa huomioon toimeentulotuen saajien palveluita suunniteltaessa.

\section{ASIASANAT: lääkkeet, toimeentulotuki, terveyserot, lääkekorvausoikeus}

KATRI AALTONEN, KAARLO LEKANDER, ELINA AHOLA, HEIKKI HIILAMO

\section{JOHDANTO}

Perustoimeentulotuen myöntäminen ja maksatus siirtyivät kunnilta Kansaneläkelaitokselle (Kela) vuoden 2017 alusta. Toimeentulotukihakemusten käsittely ruuhkautui alkuvaiheessa pahasti ja tukien maksu viivästyi, mikä aiheutti hakijoille ongelmia muun muassa perushyödykkeiden, kuten lääkkeiden, hankinnassa ja vuokranmaksussa (1). Hakemusten käsittelyongelmat osoittivat, että toimeentulotulotuki on luonteeltaan hankalampi etuus kuin muut Kelan maksamat etuudet, mihin Kelassa ei osattu varautua etukäteen $(2,3)$. Asias- ta herännyt julkinen keskustelu osoitti, kuinka tärkeä rooli toimeentulotuella on potilaan lääkehoidon mahdollistajana. Sen turvin potilaalla on varaa hankkia hänelle määrätyt lääkkeet.

Tämän tutkimuksen tavoitteena on kuvailla toimeentulotuen saajien ja ei-toimeentulotuen saajien lääkekorvausoikeuksia ja sairausvakuutuksesta korvattujen reseptilääkkeiden käyttöä Helsingissä vuonna 2010. Tutkimuksessa syvennytään suomalaisiin kansantauteihin, erityisesti mielenterveysongelmiin. Lääkkeiden käyttöä tutkimalla saadaan tietoa terveysongelmien 
yleisyydestä sekä hoitoihin saatavissa olevista ja käytetyistä resursseista $(4,5)$. Tutkimuksessa ei kuitenkaan voida osoittaa toimeentulotuen saamisen ja sairastavuuden välisen yhteyden suuntaa. Yhtäältä huono-osaisuus voi johtaa terveysongelmiin, jotka johtavat lääkkeiden käyttöön. Toisaalta toimeentulotuen tarve voi johtua terveysongelmista, sillä käytettävissä olevat tulot pienenevät ja lääkkeisiin ja terveydenhuollon maksuihin kuluu rahaa.

Aiemmissa vastaavissa tarkasteluissa on hyödynnetty terveydenhuollon palvelujen käyttötietoja sekä terveydenhuollon ja lääkkeiden kustannuksia. Vuonna 2011 pääkaupunkiseudun kunnissa toimeentulotuen saajilla oli keskimäärin muuta väestöä enemmän julkisen perusterveydenhuollon ja erikoissairaanhoidon vastaanottokäyntejä iästä ja sukupuolesta riippumatta (6). Perusterveydenhuollon vastaanottokäyntejä oli sitä enemmän mitä useampana vuonna henkilö oli saanut toimeentulotukea. Erikoissairaanhoidon psykiatrian käyntimäärissä erot toimeentulotuen saajien ja ei-toimeentulotuen saajien välillä olivat keskimäärin 7-8-kertaiset, ja muissa erikoissairaanhoidon käynneissä noin kaksinkertaiset. Erot käyntien yhteislukumäärissä toimeentulotuen saajien ja ei-toimeentulotuen saajien välillä eivät tasoittuneet, vaikka Kelan korvaamat yksityislääkärikäynnit laskettiin mukaan. Pääkaupunkiseudun kuntien asukkaiden terveydenhuollon ja sairausvakuutusetuuksien käyttötietoihin vuosilta 2006-2011 pohjautuvassa pitkittäistutkimuksessa havaittiin, että toimeentulotuen saajat käyttivät enemmän julkista erikoissairaanhoitoa toimeentulotuen saannin alkua edeltävinä ja sen jälkeisinä vuosina kuin ne, jotka eivät saaneet toimeentulotukea (7). Psykiatrian tai muun alan erikoislääkärissäkäynti, sairaalahoitojakso ja sairauspäivärahan saanti edeltävän kuukauden aikana olivat kaikki yhteydessä toimeentulotuen saantiin seuraavassa kuussa.

Verrattaessa helsinkiläisiä toimeentulotuen saajia niihin helsinkiläisiin ei-toimeentulotuen saajiin, jotka käyttivät julkisia terveyspalveluja tarkasteluvuoden 2014 aikana, huomattiin, että toimeentulotuen saanti oli yhteydessä julkisen perusterveydenhuollon ja päivystyksen vastaanottokäynteihin ja hoitojaksoihin (8). Yhteys oli voimakkain terveysasemien päihdetyöhön liittyvissä käynneissä, selviämisvastaanoton käynneissä ja psykiatrian poliklinikan käynneissä sekä akuuttipsykiatrian hoitojaksoissa. Potilasrekisteriin kirjattujen diagnoositietojen avulla havaittiin, että toimeentulotuen saanti oli voimakkaimmin yhteydessä lääkkeiden ja päihteiden aiheuttamiin elimellisiin aivo-oireyhtymiin ja käyttäytymisen häiriöihin, aikuisiän persoonallisuus- ja käyttäytymishäiriöihin, skitsofreniaan ja harhaluuloisuushäiriöihin, mielialahäiriöihin, neuroottisiin, stressiin liittyviin ja somatomorfisiin häiriöihin, bakteeri- ja infektiosairauksiin, selkäsairauksiin, ihosairauksiin ja ruoansulatuselimistön sairauksiin.

Terveydenhuollon palvelujen ja lääkkeiden käyttöä ja kustannuksia on tutkittu nuorten syrjäytymisen näkökulmasta (9). Syrjäytyneiden nuorten, joista valtaosa saa toimeentulotukea, terveydenhuollon kustannukset ja lääkekustannukset olivat suuremmat kuin niiden vain peruskoulun suorittaneiden nuorten, jotka eivät olleet syrjäytymisvaarassa. Syrjäytyneillä nuorilla oli muita nuoria enemmän etenkin psykiatrisia diagnooseja, vammoja ja myrkytyksiä sekä tartuntaja loistauteja.

Palvelujen käyttöön perustuneissa tutkimuksissa ei ollut käytettävissä työterveyshuollon käyntitietoja. Kyselytutkimuksen perusteella useammat toimeentulotuen saajat käyttävät terveyskeskuksen palveluja kuin ei-toimeentulotuen saajat, kun taas ei-toimeentulotuen saajista useammat käyttävät työterveyshuollon ja yksityislääkärien palveluja (10). Merkittävä osuus työikäisistä potilaista voi olla työterveyshuollon hoitovastuulla perusterveydenhuollon osalta (11). Monet suomalaiset kansantaudit, kuten masennus, astma, tyypin 2 diabetes ja kohonnut verenpaine voidaan suositusten mukaan hoitaa valtaosin perusterveydenhuollossa. Lääkeostotiedot ja tiedot lääkekorvausoikeuksista täydentävät palvelujen käyttöön perustuvia tutkimustietoja, sillä ne sisältävät työterveyshuollon hoitovastuulla olevien potilaiden tiedot. Aiemmin on laskettu, että toimeentulotuen saajien avohoidossa määrätyistä reseptilääkkeistä kertyvät kustannukset ovat noin kaksinkertaiset verrattuna saman ikäisiin ei-toimeentulotuen saajiin (6).

Palvelujen tai lääkkeiden käytön ja sairastavuuden välinen yhteys ei ole täydellinen, sillä käytölle voi olla saatavuuteen liittyviä esteitä. Toimeentulotuen saajat kokevat ei-toimeentulotuen saajia enemmän tyydyttämätöntä palvelujen tarvetta (10). Aiemmin on havaittu, että pitkä- 
aikaistyöttömillä on runsaasti toimintakykyyn vaikuttavia sairauksia, jotka jäävät diagnosoimatta ja hoitamatta (12). Näitä sairauksia ovat etenkin mielenterveyden häiriöt, kuten mielialahäiriöt, kehitysvammaisuus tai heikkolahjaisuus, päihderiippuvuus, muut kehitykselliset häiriöt (autismi ja ADHD) sekä persoonallisuushäiriöt.

Kyselytutkimuksen perusteella tiedetään, että toimeentulotuen saajat kokevat terveytensä muuta väestöä heikommaksi ja sairastavat ikään suhteutettuna muuta väestöä yleisemmin mielenterveysongelmia, sydän- ja verisuonisairauksia, selkäsairauksia ja syöpätauteja (10). Terveysongelmien lisäksi toimeentulotuen piiriin kuuluvilla korostuvat muut ongelmat, kuten työttömyys, asunnottomuus, päihdeongelmat, yksinäisyys, stressi, erilaiset puutteet hyvinvoinnissa ja heikentynyt elämänlaatu (13-15).

Toimeentulotuen saajat poikkeavat ei-toimeentulotuen saajista sosiodemografisilta ja -ekonomisilta ominaisuuksiltaan. Nämä erot vaikuttavat itsenäisesti toimeentulotuen saajan terveyteen sekä terveyspalvelujen ja lääkkeiden käyttöön. Siksi ikään ja sukupuoleen suhteutettu vertailu toimeentulotuen saajien ja ei-toimeentulotuen saajien välillä tukee lähinnä yleistä käsitystä sosioekonomisista terveyseroista. Erikoissairaanhoidon palvelujen käytössä ero toimeentulotuen saajien ja muun väestön välillä säilyi, vaikka erot koulutustasossa huomioitiin sekoittavana tekijänä (7). Nuorilla syrjäytymisen kroonisuuden on havaittu olevan yhteydessä suurempiin terveydenhuollon kustannuksiin ja lääkekustannuksiin, kun kroonisesti syrjäytyneitä verrattiin nuoriin, joiden syrjäytyminen oli lyhyempiaikaista tai jotka olivat syrjäytymisvaarassa (9). Toimeentulotuen saajissa maahanmuuttajien osuus on huomattavasti suurempi kuin väestössä keskimäärin (16). Maahanmuuttajien ja kantaväestön välillä, samoin kuin eri maahanmuuttajaryhmien välillä, on havaittu eroja lääkäripalvelujen ja reseptilääkkeiden käytössä (17). Erot voivat liittyä erilaisten tausta- ja riskitekijöiden lisäksi eroihin sairauksien diagnosoinnissa, terveyspalvelujen käytössä ja saatavuudessa sekä subjektiivisten tulosten kohdalla kulttuurisidonnaisiin eroihin sairauden kokemisessa (18).

Tässä tutkimuksessa vakioidaan aiempaa kattavammin toimeentulotuen saajien ja ei-toimeentulotuen saajien taustatekijöiden erot. Näin pystytään erittelemään toimeentulotuen saami- sen itsenäinen yhteys lääkkeiden käyttöön ja lääkekorvausoikeuksiin. Lisäksi tutkimuksessa selvitetään, onko yhteys samanlainen kantaväestöllä ja eri maahanmuuttajaryhmissä. Tutkimus auttaa ymmärtämään aiempaa paremmin toimeentulotuen saamisen ja sairastavuuden välistä yhteyttä. Näin ollen tutkimuksen tuloksia voidaan hyödyntää toimeentulotuen saajien palvelujen arvioinnissa ja kehittämisessä.

\section{AINEISTO JA MENETELMÄT}

\section{TUTKIMUSAINEISTO JA LUOKITTELUT}

Tutkimuksen tulokset pohjautuvat Kaarlo Lekanderin pro gradu -tutkielmaan (19).

Tutkimuksessa käytettiin useasta rekisteristä yhdistettyä vuotta 2010 kuvaavaa kokonaisaineistoa. Aineisto sisältää tiedot jokaisesta koko vuoden 2010 vakituisesti Helsingissä asuneesta täysiikäisestä, joiden kantaväestöön kuuluminen tai maahanmuuttajatausta oli tiedossa. Tutkimuksen ulkopuolelle jäivät henkilöt, jotka eivät olleet Suomen sosiaaliturvan piirissä. Tutkimuksessa ei myöskään ole käytettävissä tietoja toimeentulotuesta, jota on maksettu muualta kuin Helsingin kaupungin sosiaalitoimesta.

Toimeentulotuen saajiksi luokiteltiin henkilöt, jotka olivat vuoden 2010 aikana saaneet toimeentulotukea, sisältäen sekä henkilön, jonka nimissä toimeentulotukipäätös oli tehty, että päätökseen osallisen puolison. Toimeentulotukitiedot saatiin TotuHelsinki-aineistosta, joka sisältää vuosilta 2008-2010 Helsingin kaupungin toimeentulotuen asiakasrekisteriin pohjautuvat tiedot perheelle myönnetystä toimeentulotuesta, tuen saamisen perusteena olleet tiedot sekä perheen taustatietoja (20). Aineisto ei kuitenkaan sisällä tietoja päätökseen osallisista lapsista, minkä vuoksi tutkimus rajattiin aikuisväestöön. Toimeentulotuen saamisen kesto luokiteltiin toimeentulotukitilastoinnin mukaan: 1-3 kuukautta vuodessa, 4-9 kuukautta vuodessa tai 10-12 kuukautta vuodessa (21).

Kelan käytössä olevista rekistereistä poimittiin seuraavat tiedot koko Helsingin väestölle vuodelta 2010: ikä ja sukupuoli, veronalaiset ansio- ja pääomatulot, voimassa olleet lääkekorvausoikeudet, lääkeostotiedot sekä tiedot maksetusta opintorahasta ja opintotuen asumislisästä. Henkilöt luokiteltiin vuoden 2010 henkilökoh- 
taisten veronalaisten ansio- ja pääomatulojen mukaan tuloviidenneksiin (I: alle 9665,26 €; II: 9665,26-19568,52 €; III: 19568,53-30042,49 $€$; IV: $30042,50-43615,16 €$; V: yli 43615,16 $€)$. Henkilökohtaisia tuloja käytettiin, koska tutkimusaineistossa ei ole kotitalouksien jäsenten yhdistämiseksi tarvittavia tietoja. Henkilökohtaiset tulotiedot ovat kotitalouden tuloja selvästi karkeampi mittari, sillä kotitalouden muiden henkilöiden tulot vaikuttavat henkilön käytettävissä oleviin tuloihin. Aiemmin on havaittu, että henkilökohtaisten tulojen käyttö tarkastelussa pienentää hieman alimman tuloryhmän lääkekorvauksia saaneiden osuutta verrattuna tarkasteluun, jossa käytetään kotitalouden tuloihin perustuvaa luokittelua (22). Syynä voivat olla henkilöt, jotka elävät kotitalouden muiden henkilöiden tuloilla ja jotka eivät käytä reseptilääkkeitä mahdollisesti hyvän terveydentilan takia.

Opiskelijoiksi luokiteltiin henkilöt, joille oli maksettu opintorahaa tai opintotuen asumislisää ainakin yhtenä kuukautena vuoden 2010 aikana. Opiskelijoiden osuus vakioitiin, sillä he muodostavat huomattavan osan nuorista toimeentulotuen saajista (23). Opiskelijoilla opintojen aikainen pienituloisuus on usein ohimenevää ja opiskelijoille suunnatut terveyspalvelut voivat vaikuttaa terveyspalvelujen saatavuuteen ja käyttöön. Opiskelijoita voidaan toimeentulotuen saajien ryhmässä pitää pitkäaikaistyöttömiä tai työkyvyttömiä parempiosaisina. Toimeentulotukea saavia kotitalouksia oli Helsingissä vuonna 2010 aiempaa enemmän, ja heidän määränsä oli kasvanut merkittävästi jo vuonna 2009 kansainvälisen talouslaman vuoksi. Kasvuun vaikuttivat erityisesti nuorten opiskelijoiden, työttömien ja lomautettujen hakeutuminen toimeentulotuen piiriin (24).

Henkilöt jaoteltiin aiemmassa (16) tutkimuksessa käytettyjen, väestötietoihin perustuvien maahanmuuttotietojen mukaisesti kantaväestöön, OECD-maista saapuneisiin, entisen Neuvostoliiton alueelta (lukuun ottamatta Viroa) saapuneisiin ja muista maista saapuneisiin, joihin kuuluivat esimerkiksi pakolaisten lähtömaista Afrikasta ja Lähi-idästä saapuneet. Lähtömaahan perustuvan jaottelun tarkoitus on ottaa huomioon maahanmuuttajan taustaan liittyviä havainnoimattomia tekijöitä, kuten koulutus ja kielitaito, jotka voivat vaikuttaa hoitojen käyttöön, saatavuuteen ja saavutettavuuteen.

\section{LÄÄKEKORVAUSOIKEUDET JA LÄ̈̈KKEIDEN KÄYTTÖ}

Lääkkeiden korvausoikeudet ovat lääkärin toteamien vaikeiden tai pitkäaikaisten sairauksien perusteella myönnettäviä henkilökohtaisia sairausvakuutusetuuksia, jotka oikeuttavat suurempiin lääkekorvauksiin $(25,26)$. Ylempään erityiskorvausluokkaan kuuluvia sairauksia ovat esimerkiksi syöpäsairaudet ja epilepsia. Alempaan erityiskorvausluokkaan puolestaan kuuluvat puolestaan esimerkiksi sydän- ja verisuonisairaudet. Erityiskorvauksien lisäksi korvausoikeuksiin lukeutuvat rajoitetut korvausoikeudet, joilla pyritään kohdentamaan kalliit lääkehoidot niistä eniten hyötyvillä potilasryhmille. Lääkkeiden korvausoikeuksia käytetään Kelan kansantauti- ja sairastavuusindeksin ja Terveyden ja hyvinvoinnin laitoksen (THL) kansanterveysindeksin laskennassa $(27,28)$. Lisäksi niitä voidaan käyttää mittaamaan sairastavuutta epidemiologisissa tutkimuksissa (29).

Henkilökohtaiset korvausoikeudet mittaavat sairastavuutta spesifisti, sillä ne edellyttävät lääkärin diagnosoimaa ja lääkärinlausunnolla varmistettua sairautta. Korvausoikeudet eivät kuitenkaan kata kaikkia vaikeita sairauksia eikä kaikille henkilöille välttämättä haeta heille kuuluvia korvausoikeuksia. Toisaalta kaikilla korvausoikeuden saaneilla ei enää ole tarvetta lääkehoitoon. Korvausoikeuden kriteerit voivat poiketa sairauden diagnosointikriteereistä, ja lievemmät tautimuodot voivat edellyttää lääkehoitoa, vaikka erityiskorvauksen ehdot eivät täyttyisi. Erityiskorvauksen mielenterveyden häiriöiden lääkkeistä voi saada vain vaikeimmissa, psykoottisia oireita sisältävissä sairauksissa. Masennuksen ja ahdistuneisuuden lääkehoidot jäävät siksi erityiskorvauksien ulkopuolelle. Näissä tapauksissa henkilö saa yleensä lääkkeestä peruskorvausta.

Kaikki lääkeostot, joista on maksettu perustai erityiskorvausta kirjautuvat Kelan rekisteriin. Lääkeostot indikoivat siten sairauksia korvausoikeuksia laajemmin, mutta samalla epäspesifimmin, sillä lääkeoston perusteella ei tiedetä mihin käyttötarkoitukseen lääkettä on yksittäiselle henkilölle määrätty. Lääkeostoja käytetään sairastavuuden mittarina lääkkeen pääkäyttötarkoituksen mukaan, joka yleensä perustuu lääkeaineiden anatomis-terapeuttis-kemiallisen (Anatomical Therapeutic Chemical, ATC) luokitteluun (30). On huomattava, että monia lääkkeitä voidaan käyttää useaan tarkoitukseen, ku- 
ten sydän- ja verisuonitautien lääkkeitä voidaan käyttää migreenin estohoidossa.

Tässä tutkimuksessa tarkasteltiin toimeentulotuen saajien tutkimusvuoden 2010 aikana voimassa olleita ylempiä ja alempia erityiskorvausoikeuksia sekä rajoitettuja peruskorvausoikeuksia verrattuna ei-toimeentulotuen saajiin. Tarkemmin tarkasteltiin 1) vaikeisiin mielenterveysongelmiin liittyviä korvausoikeuksia (korvausnumerot 112 ja 188); 2) sydän- ja verisuonisairauksiin liittyviä korvausoikeuksia (korvausnumerot 201, 205, 206, 207, 211, 213, 280, $315,342)$; 3) astmaattisiin sairauksiin liittyviä korvausoikeuksia (korvausnumero 203); sekä 4) diabetekseen liittyviä korvausoikeuksia (korvausnumero 103). Tutkimuksessa katsottiin, että henkilöllä on korvausoikeus, mikäli hänen oikeutensa oli voimassa ainakin yhden päivän tutkimusvuoden 2010 aikana.

Toimeentulotuen saajien ja ei-toimeentulotuen saajien lääkkeiden käyttöä tutkimusvuoden aikana verrattiin seuraavissa lääkeryhmissä: 1) mielenterveysongelmien lääkkeet (ATC-ryhmät N05A, N05B, N05C, N06A, N06C); 2) sydänja verisuonisairauksien lääkkeet (ATC-ryhmät B01AA，B01AC，C01A，C01B，C01D，C02A, C02C, C02D, C02K, C03A, C03B, C03C, C03D, C03E, C07A, C07B, C07F, C08C, C08D, C09A, C09B, C09C, C09D, C09X, C10A); 3) astmaattisiin sairauksiin liittyvät lääkkeet (ATC-ryhmä R03); sekä 4) diabeteslääkkeet (ATC-ryhmä A10). Lääkettä käyttänyt määriteltiin tutkimuksessa henkilöksi, joka oli ostanut kyseiseen lääkeryhmään kuuluvaa valmistetta ainakin kerran tutkimusvuoden 2010 aikana.

\section{TILASTOMENETELMÄT}

Lääkekorvausoikeuksia ja lääkkeiden käyttöä verrattiin toimeentulotuen saajien ja ei-toimeentulotuen saajien välillä. Menetelmänä käytettiin vakiointia, jolla ei-toimeentulotuen saajien ikä-, sukupuoli-, maahanmuuttajatausta-, tulo- ja opiskelijajakauma vakioitiin tutkimusaineistosta laskettujen painokerrointen avulla vaiheittain vastaamaan toimeentulotuen saajien jakaumaa. Vakioitavat tekijät valittiin sillä perusteella, että niillä tiedetään olevan itsenäinen vaikutus sairastavuuteen tai lääkkeiden käyttöön. Opiskelijoiden osuus otettiin mukaan vakioiviin tekijöihin, koska opiskelu on yleinen syy nuorten toimeentulotuen saajien pienituloisuuteen ja koska opis- kelijoiden osuus oli vuonna 2010 erityisen suuri (24).

Vaikeiden mielenterveyden häiriöiden korvausoikeuksia sekä eri psyykenlääkkeiden käyttöä tarkasteltiin toimeentulotuen saantikuukausien määrän mukaan miehillä ja naisilla. Psyykenlääkityksen yleisyyteen liittyviä tekijöitä tarkasteltiin logistisella regressioanalyysilla. Lääkityksen yleisyyttä arvioitiin lääkekorvausoikeuksien ja lääkeostojen perusteella. Regressioanalyysi tehtiin erikseen kantaväestölle ja jokaiselle maahanmuuttajaryhmälle, koska etukäteen ei ollut tietoa siitä, onko psyykenlääkkeiden käytön ja toimeentulotuen välinen yhteys samanlainen eri ryhmissä. Aiemmassa tutkimuksessa on havaittu, että maahanmuuttajilla esiintyy mielenterveysoireita muuta väestöä yleisemmin, mutta he käyttävät vähemmän mielenterveyspalveluja, mikä voi tarkoittaa tyydyttymätöntä palvelujen tarvetta (18). Psyykenlääkitystä mittaava vastemuuttuja muodostettiin korvausoikeuksien ja lääkeostojen perusteella ehdolla "on korvausoikeus vaikean mielenterveysongelman perusteella tai ainakin yksi psyykenlääkeosto vuoden aikana”. Selittäviin tekijöihin otettiin mukaan jo vakioinneissa käytettyjen tekijöiden lisäksi toimeentulotuen saannin kesto tutkimusvuoden aikana. Tulokset esitetään ristitulosuhteina (OR, odds ratio) ja niiden $95 \%$ :n luottamusväleinä (LV). Tilastollista merkitsevyyttä testattiin $5 \%$ :n merkitsevyystasolla.

Aineiston muokkaus ja tilastolliset analyysit tehtiin SAS Instituten SAS 9.3 -ohjelmistolla.

\section{TULOKSET}

\section{TUTKIMUSAINEISTON KUVAUS}

Aineisto sisältää 37836 toimeentulotuen saajan ja 430977 ei-toimeentulotuen saajan tiedot vuodelta 2010 (taulukko 1). Toimeentulotuen saajista on miehiä $52 \%$ ja ei-toimeentulotuen saajista $46 \%$. Väestötilastojen mukaan vuoden 2010 lopussa Helsingissä asuvista vähintään 18-vuotiaista henkilöistä oli miehiä $46 \%$ ja naisia $54 \%$ (31), joten miehet ovat toimeentulotuen saajissa yliedustettuja. Toimeentulotuen saajien ikärakenne on nuorempi kuin ei-toimeentulotuen saajien. Vuoden 2010 lopun väestötilastoihin (31) verrattuna toimeentulotuen saajissa ovat yliedustettuja 18-24-vuotiaat (18\% vs. väestössä $12 \%$ ), 
Taulukko 1. Toimeentulotuen saajien $(\mathrm{N}=37836)$ ja ei-toimeentulotuen saajien $(\mathrm{N}=430997)$ jakaumat iän, sukupuolen, maahanmuuttajataustan, tulojen ja opiskelijoiden osuuden mukaan Helsingissä vuonna 2010, sarake- $\%$.

\begin{tabular}{|c|c|c|c|}
\hline & $\begin{array}{c}\text { Toimeentulotuen saajat } \\
(\%)\end{array}$ & $\begin{array}{c}\text { Ei-toimeentulotuen } \\
\text { saajat }(\%)\end{array}$ & $\begin{array}{c}\text { Yhteensä } \\
(\%)\end{array}$ \\
\hline \multicolumn{4}{|l|}{ Ikäryhmä } \\
\hline $18-24$ & 18,1 & 10,0 & 10,6 \\
\hline $25-34$ & 23,2 & 20,8 & 21,0 \\
\hline $35-44$ & 20,1 & 16,3 & 16,6 \\
\hline $45-54$ & 19,6 & 16,4 & 16,7 \\
\hline $55-64$ & 12,8 & 16,2 & 15,9 \\
\hline $65-74$ & 3,8 & 10,9 & 10,3 \\
\hline 75- & 2,4 & 9,5 & 8,9 \\
\hline \multicolumn{4}{|l|}{ Sukupuoli } \\
\hline Mies & 52,4 & 45,5 & 46,0 \\
\hline Nainen & 47,6 & 54,6 & 54,0 \\
\hline \multicolumn{4}{|c|}{ Maahanmuuttajatausta } \\
\hline Kantaväestö & 72,8 & 92,1 & 90,6 \\
\hline OECD & 4,8 & 3,4 & 3,5 \\
\hline Ent. Neuvostoliitto & 6,9 & 1,8 & 2,2 \\
\hline Muut & 15,6 & 2,7 & 3,8 \\
\hline \multicolumn{4}{|l|}{ Tuloviidennes } \\
\hline I (pienituloisin) & 68,4 & 15,8 & 20,0 \\
\hline II & 22,8 & 19,8 & 20,0 \\
\hline III & 6,8 & 21,2 & 20,0 \\
\hline IV & 1,8 & 21,6 & 20,0 \\
\hline $\mathrm{V}$ (suurituloisin) & 0,3 & 21,7 & 20,0 \\
\hline \multicolumn{4}{|l|}{ Opiskelija } \\
\hline $\mathrm{Ei}$ & 88,6 & 91,0 & 90,8 \\
\hline Kyllä & 11,5 & 9,0 & 9,2 \\
\hline
\end{tabular}

25-34-vuotiaat ( $23 \%$ vs. $22 \%$ ), 35-44-vuotiaat $(20 \%$ vs. $16 \%), 45-54$-vuotiaat $(20 \%$ vs. $16 \%$ ) ja aliedustettuja 55-64-vuotiaat (13\% vs. $15 \%$ ), 65-74-vuotiaat (4\% vs. $10 \%$ ) ja vähintään 75 -vuotiaat ( $2 \%$ vs. $8 \%$ ).

Maahanmuuttajia on toimeentulotuen saajissa selvästi enemmän (27 \%) kuin ei-toimeentulotuen saajissa $(8 \%)$. Toimeentulotuen saajissa suurin maahanmuuttajaryhmä ovat muista kuin OECD-maista tai entisen Neuvostoliiton alueelta saapuneet $(16 \%)$ kun taas ei-toimeentulotuen saajissa suurin ryhmä ovat OECD-maista saapuneet $(3 \%)$. Toimeentulotuen saajien tulot luonnollisesti eroavat ei-toimeentulotuen saajien tuloista. Toimeentulotuen saajista $68 \%$ ja ei-toimeentulotuen saajista $16 \%$ kuuluu aineiston alimpaan tuloviidennekseen. Toimeentulotuen saamista ylemmissä tuloryhmissä voi selittää tulojen epätasainen jakautuminen vuoden ajalle sekä ehkäisevä toimeentulotuki. Toimeentulotuen saajiin kuuluu enemmän opiskelijoita kuin ei-toimeentulotuen saajiin (12\% vs. $9 \%$ ). Tukea saaneet opiskelijat poikkeavat muista toimeentulotuen saajista siten, että he saavat yleisemmin tukea vain 1-3 kuukautta vuoden aikana. Tätä eroa selittänevät lukuvuosien aikana saatavat opintoetuudet, joita ei kuitenkaan automaattisesti myönnetä kesäkuukausille.

\section{KORVAUSOIKEUDET JA LÄÄKEOSTOT TOIMEENTULOTUEN SAAJILLA JA EI-TOIMEENTULOTUEN SAAJILLA}

Kun erot taustatekijöissä vakioidaan, useammalla toimeentulotuen saajalla kuin ei-toimeentulotuen saajalla on lääkärin toteamasta sairaudesta johtuvia korvausoikeuksia ja tarkasteltuihin sairauksiin liittyviä lääkeostoja (taulukko 2). Ero on samansuuntainen korvausoikeuksissa yhteensä ( $20 \%$ vs. $15 \%$ ) sekä erikseen vaikean 


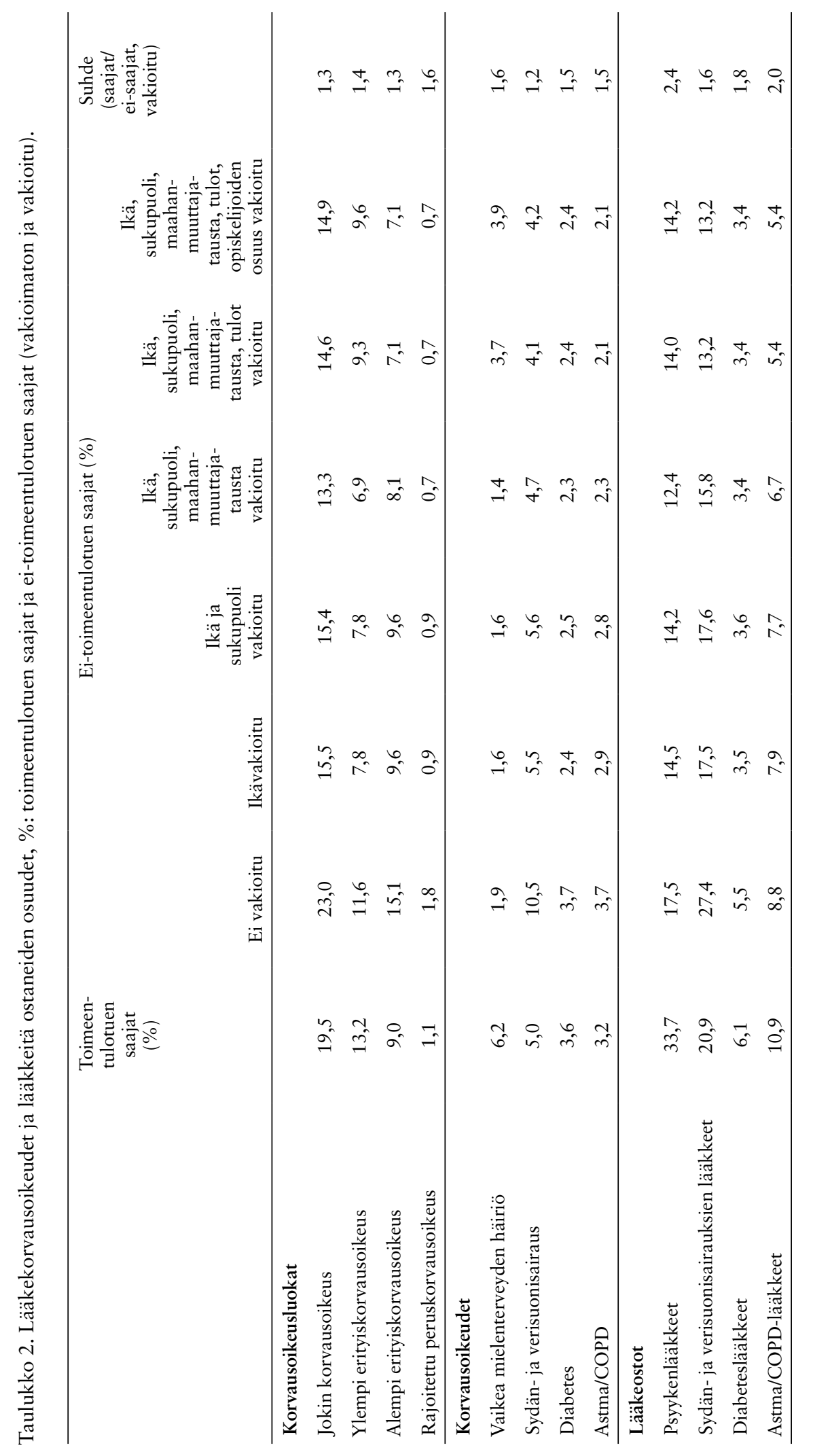


Taulukko 3. Vaikeiden mielenterveyden häiriöiden korvausoikeudet ja eri psyykenlääkkeitä ostaneiden osuudet miehistä ja naisista toimeentulotuen keston (kuukautta) mukaan, \%.

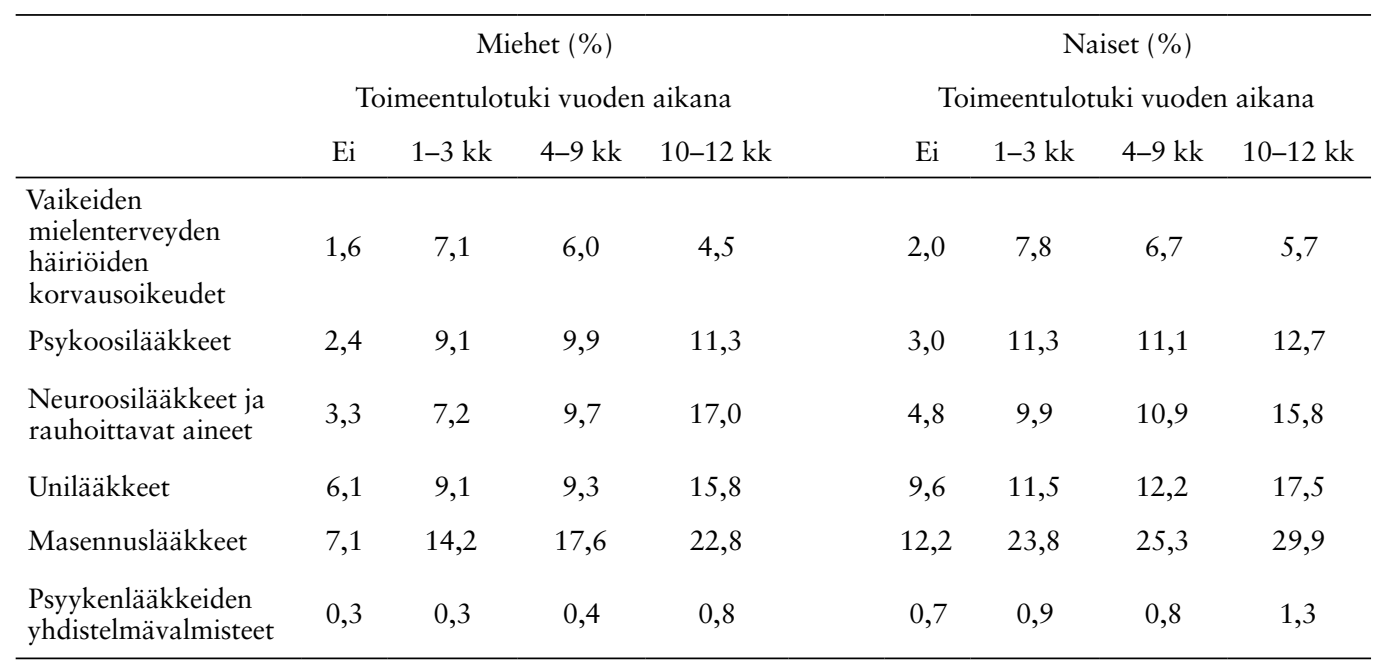

tai pitkäaikaisen sairauden nojalla myönnettävissä ylemmissä (13\% vs. $10 \%$ ) ja alemmissa erityiskorvausoikeuksissa (9 \% vs. $7 \%$ ) ja erityisen kalliisiin lääkehoitoihin liittyvissä rajoitetuissa korvausoikeuksissa $(1,1 \%$ vs. $0,7 \%)$. Sairausryhmittäin ero toimeentulotuen saajien ja ei-toimeentulotuen saajien välillä on suurin vaikeisiin mielenterveyden häiriöihin liittyvissä erityiskorvausoikeuksissa (6\% vs. $4 \%$ ) ja psyykenlääkkeitä ostaneissa ( $34 \%$ vs. $14 \%$ ).

Ennen vakiointia korvausoikeudet ovat ei-toimeentulotuen saajilla yleisempiä $(23 \%)$ ja vakiointien jälkeen harvinaisempia $(15 \%)$ kuin toimeentulotuen saajilla $(20 \%)$. Ikävakioinnin merkitys on suuri, sillä korvausoikeudet yleistyvät iän myötä. Maahanmuuttajataustarakenteen vakiointi suurentaa eroja, koska maahanmuuttajilla on kantaväestöä harvemmin korvausoikeuksia. Tulojen vakiointi puolestaan pienentää eroja, sillä pienituloisilla on suurituloisia yleisemmin korvausoikeuksia. Vakiointien vaikutus on samansuuntainen, kun vertaillaan korvausoikeuksia yhteensä tai erikseen alempia erityiskorvausoikeuksia tai rajoitettuja korvausoikeuksia. Sen sijaan ylempiä erityiskorvausoikeuksia on toimeentulotuen saajilla ei-toimeentulotuen saajia yleisemmin jo ennen vakiointia, koska ylemmät erityiskorvausoikeudet painottuvat muita korvausoikeuksia vahvemmin pienituloisille (22).

\section{PSYYKENLÄÄKITYS}

Vaikeiden mielenterveyden häiriöiden korvausoikeuksia sekä eri psyykenlääkkeiden käyttöä tarkasteltiin suhteessa toimeentulotuen käyttöön vuoden aikana (taulukko 3). Korvausoikeudet ovat yleisimpiä niillä toimeentulotuen saajilla, jotka saivat toimeentulotukea vain muutamia kuukausia vuoden aikana (7-8 \%). Lähes koko vuoden toimeentulotukea saaneilla korvausoikeuksia on tätä harvemmin (5-6\%), mutta yleisemmin kuin ei-toimeentulotukea saaneilla ( $2 \%)$. Kaikkien eri psyykenlääkkeiden käyttö on sitä yleisempää, mitä useamman kuukauden toimeentulotukea henkilö on saanut. Korvausoikeudet ja eri psyykenlääkkeiden ostot ovat naisilla yleisempiä kuin miehillä toimeentulotuen saannista riippumatta.

Logistisen regressioanalyysin perusteella psyykenlääkitys on samansuuntaisesti yhteydessä toimeentulotuen saantiin kantaväestössä ja eri maahanmuuttajaryhmissä (taulukko 4). Psyykenlääkitys on toimeentulotuen asiakkailla sitä yleisempää, mitä useamman kuukauden he saivat toimeentulotukea tarkastellun vuoden aikana (toimeentulotukea 1-3 kuukautta, 4-9 kuukautta ja 10-12 kuukautta saaneilla ristitulosuhteet (OR) 2,8 [95 \%:n LV 2,7-2,9], 3,7 [3,5-3,8] ja 5,3 [5,0-5,5] kantaväestössä; 2,4 [1,9-3,2], 4,0 [3,2-5,0] ja 7,8 [6,4-9,5] OECD-maista saapu- 
Taulukko 4. Toimeentulotuen saannin, iän, sukupuolen, tulojen ja opiskelun yhteys psyykenlääkkeen ostoon tai vaikean mielenterveyshäiriön erityiskorvausoikeuteen maahanmuuttajataustan mukaan, ristitulosuhde (odds ratio = OR) ja suluissa sen $95 \%$ :n luottamusväli (LV).

\begin{tabular}{|c|c|c|c|c|}
\hline & $\begin{array}{l}\text { Kantaväestö } \\
\text { OR (LV) }\end{array}$ & $\begin{array}{l}\text { OECD } \\
\text { OR (LV) }\end{array}$ & $\begin{array}{l}\text { Ent. Neuvostoliitto } \\
\text { OR (LV) }\end{array}$ & $\begin{array}{l}\text { Muut } \\
\text { OR (LV) }\end{array}$ \\
\hline \multicolumn{5}{|c|}{$\begin{array}{l}\text { Toimeentulotuki vuonna } \\
2010\end{array}$} \\
\hline Ei toimeentulotukea & 1,00 & 1,00 & 1,00 & 1,00 \\
\hline 1-3 kuukautta & $2,78(2,65 ; 2,91)$ & $2,44(1,87 ; 3,18)$ & $2,31(1,80 ; 2,96)$ & $2,04(1,58 ; 2,64)$ \\
\hline 4-9 kuukautta & $3,67(3,50 ; 3,85)$ & $4,03(3,24 ; 5,01)$ & $2,35(1,91 ; 2,90)$ & $3,02(2,51 ; 3,64)$ \\
\hline 10-12 kuukautta & $5,27(5,03 ; 5,53)$ & $7,79(6,36 ; 9,54)$ & $3,57(2,93 ; 4,35)$ & $5,10(4,35 ; 5,98)$ \\
\hline \multicolumn{5}{|l|}{ Ikäryhmä } \\
\hline $18-24$ & $0,29(0,28 ; 0,31)$ & $0,38(0,28 ; 0,50)$ & $0,40(0,29 ; 0,54)$ & $0,24(0,18 ; 0,32)$ \\
\hline $25-34$ & $0,57(0,55 ; 0,58)$ & $0,54(0,46 ; 0,64)$ & $0,46(0,37 ; 0,57)$ & $0,47(0,39 ; 0,56)$ \\
\hline $35-44$ & $0,80(0,77 ; 0,82)$ & $0,73(0,62 ; 0,86)$ & $0,63(0,52 ; 0,77)$ & $0,74(0,63 ; 0,86)$ \\
\hline $45-54$ & 1,00 & 1,00 & 1,00 & 1,00 \\
\hline $55-64$ & $1,15(1,12 ; 1,18)$ & $1,29(1,08 ; 1,55)$ & $1,07(0,88 ; 1,32)$ & $1,38(1,09 ; 1,75)$ \\
\hline $65-74$ & $1,15(1,12 ; 1,19)$ & $1,49(1,13 ; 1,97)$ & $0,94(0,71 ; 1,24)$ & $1,32(0,90 ; 1,94)$ \\
\hline $75-$ & $1,85(1,80 ; 1,90)$ & $2,91(2,22 ; 3,81)$ & $1,29(0,97 ; 1,72)$ & $1,04(0,55 ; 1,97)$ \\
\hline \multicolumn{5}{|l|}{ Sukupuoli } \\
\hline Mies & 1,00 & 1,00 & 1,00 & 1,00 \\
\hline Nainen & $1,51(1,49 ; 1,53)$ & $1,69(1,51 ; 1,89)$ & $1,94(1,67 ; 2,26)$ & $1,09(0,96 ; 1,22)$ \\
\hline \multicolumn{5}{|l|}{ Tuloviidennes } \\
\hline I & 1,00 & 1,00 & 1,00 & 1,00 \\
\hline II & $1,31(1,28 ; 1,35)$ & $1,96(1,66 ; 2,33)$ & $1,13(0,92 ; 1,39)$ & $1,15(0,96 ; 1,37)$ \\
\hline III & $1,01(0,98 ; 1,04)$ & $2,34(1,97 ; 2,77)$ & $1,16(0,93 ; 1,44)$ & $1,55(1,27 ; 1,89)$ \\
\hline IV & $0,84(0,82 ; 0,87)$ & $2,41(2,00 ; 2,90)$ & $1,30(1,00 ; 1,69)$ & $2,09(1,64 ; 2,65)$ \\
\hline V & $0,77(0,75 ; 0,79)$ & $2,35(1,90 ; 2,91)$ & $1,81(1,33 ; 2,45)$ & $1,73(1,24 ; 2,41)$ \\
\hline \multicolumn{5}{|l|}{ Opiskelija } \\
\hline $\mathrm{Ei}$ & 1,00 & 1,00 & 1,00 & 1,00 \\
\hline Kyllä & $0,80(0,76 ; 0,83)$ & $1,87(1,42 ; 2,45)$ & $0,89(0,64 ; 1,23)$ & $1,39(1,06 ; 1,82)$ \\
\hline
\end{tabular}

neilla; 2,3 [1,8-3,0], 2,4 [1,9-2,9] ja 3,6 [2,9$4,3]$ entisen Neuvostoliiton alueelta saapuneilla; ja $2,0[1,6-2,6], 3,0[2,5-3,6]$ ja $5,1[4,4-6,0]$ muista kuin edellä mainituista maista saapuneilla, kun vertailuryhmänä on ei-toimeentulotuen saajat). OECD-maista saapuneilla psyykenlääkkeiden käytön yleisyys lisääntyy jonkin verran enemmän kuin kantaväestöllä toimeentulotukikuukausien määrän kasvaessa.

Kantaväestöllä korkeampi ikä on yhteydessä yleisempään psyykenlääkitykseen (18-44-vuotiailla ristitulosuhteet $0,3-0,8$ ja vähintään 55-vuotiailla 1,2-1,9 kun vertailuryhmänä ovat 45-54-vuotiaat). OECD-maista saapuneilla iän ja sukupuolen yhteys psyykenlääkitykseen on samansuuntainen kuin kantaväestöllä. Entisen Neuvostoliiton alueelta ja muista kuin edellä mainituista maista saapuneilla iän yhteys on samansuuntainen kuin kantaväestöllä, mutta vanhimmissa ikäryhmissä erot eivät ole tilastollisesti merkitseviä. Naissukupuoli on yhteydessä yleisempään psyykenlääkitykseen kantaväestössä (1,5 [1,5-1,5]), OECD-maista saapuneilla $(1,7$ [1,5-1,9]) ja entisen Neuvostoliiton alueelta saapuneilla $(1,9[1,7-2,3])$. Muista kuin näistä maista saapuneilla ero sukupuolten välillä ei ole tilastollisesti merkitsevä $(1,1$ [1,0-1,2]).

Tulojen vaikutus on erisuuntainen kantaväestössä ja maahanmuuttajilla. Kantaväestössä korkeampi tulotaso on kääntäen yhteydessä psyykenlääkityksen yleisyyteen (tuloryhmässä IV ja $\mathrm{V}$ ristitulosuhteet $0,8[0,8-0,9]$ ja $0,8[0,7-0,8]$, kun vertailuryhmänä on tuloryhmä I), maahanmuuttajilla sen sijaan korkeampi tulotaso on yhteydessä yleisempään psyykenlääkitykseen (tuloryhmässä $\mathrm{V}$ ristitulosuhteet 1,7-2,4). 


\section{POHDINTA}

Tutkimuksessa verrattiin toimeentulotuen saajien ja ei-toimeentulotuen saajien lääkekorvausoikeuksia ja lääkkeiden käyttöä Helsingissä vuonna 2010. Tutkimus osoittaa, että toimeentulotuen saajista useammalla on vaikeista ja pitkäaikaisista sairauksista tai kalliista lääkehoidoista kertovia korvausoikeuksia sekä tarkasteltujen kansansairauksien lääkeostoja kuin ei-toimeentulotuen saajilla, kun erot ikä- ja sukupuolirakenteessa, maahanmuuttajataustassa, tulotasossa ja opiskelijoiden osuudessa vakioidaan. Kaikkien eri psyykenlääkkeiden käyttö yleistyy toimeentulotuen saantikuukausien määrän myötä, mutta vaikeista mielenterveyden häiriöistä johtuvat korvausoikeudet ovat yleisempiä vain muutamia kuukausia toimeentulotukea saaneilla. Psyykenlääkityksen ja toimeentulotuen saannin yhteys vaikuttaa olevan samansuuntainen kantaväestössä ja eri maahanmuuttajaryhmissä.

Tutkimus vahvistaa aiempia, eri mittareilla saatuja tuloksia siitä, että toimeentulotuen saajat sairastavat muuta väestöä enemmän, etenkin mielenterveyden häiriöitä $(6-8,10)$. Tulos ei yllätä, sillä mielenterveysongelmat häiritsevät usein merkittävästi työ- ja toimintakykyä (32). Vaikeat diagnosoidut psyykensairaudet eivät kuitenkaan näytä selittävän yleistä psyykenlääkkeiden käyttöä lähes koko vuoden toimeentulotukea saaneilla. Eläke-etuuksien työmarkkinatukea korkeampi nettotaso saattaa selittää havaintoa, sillä Suomessa vaikeimpia diagnosoituja psykiatrisia sairauksia, kuten skitsofreniaa, sairastavat ovat usein eläkkeellä (33). He eivät siksi välttämättä saa tai tarvitse toimeentulotukea jatkuvasti. Lisäksi psykiatriset laitoshoitojaksot, joiden aikana ei synny avohoidon lääkeostotietoja, saattavat selittää havaintoa. Sen sijaan henkilöt, joiden mielenterveysongelmat tai oireet ovat epäspesifimpiä tai puutteellisesti diagnosoituja tai joilla on mielenterveysoireiden lisäksi vaikeita päihdeongelmia, saattavat jäädä pitkäaikaisesti toimeentulotuen varaan.

Pienituloisilla ja vähän koulutetuilla on huonompi koettu terveys ja enemmän pitkäaikaissairauksia kuin parempituloisilla ja korkeammin koulutetuilla (34). Tässä tutkimuksessa havaitut erot korvausoikeuksissa ja lääkeostoissa toimeentulotuen saajien ja ei-toimeentulotuen saajien välillä olivat selvät, vaikka erot tulotasossa vakioitiin. Tutkimus vahvistaa siten käsitystä siitä, että toimeentulotuen saajilla pienituloisuus on vain yksi tekijä kasautuvassa huono-osaisuudessa (13-15). Tutkimuksessa havaittuja eroja lääkkeiden käytössä todennäköisesti selittää valikoituminen. Toimeentulotuen saajiksi valikoituu sairaampia henkilöitä sekä sitä kautta enemmän ja kalliimpia lääkkeitä käyttäviä, sillä sairaus voi sekä heikentää tulonhankkimismahdollisuuksia että lisätä terveysmenojen kautta toimeentulotuen tarvetta. Erot korvausoikeuksissa ja aiempi pitkittäistutkimus erikoissairaanhoidon käytöstä tukevat tätä oletusta pois sulkematta yhteyden kaksisuuntaisuuden mahdollisuutta (7).

Eroihin lääkeostoissa voi liittyä lääkkeiden ali- tai ylikäyttöä. Toimeentulotuen saajat säästivät jo ennen perustoimeentulotuen siirtoa Kelaan selvästi muuta väestöä yleisemmin lääkkeistä ja lääkärissäkäynneistä (10). Vaikka perustoimeentulotuki voi korvata lääkärin määräämät reseptilääkkeet kokonaan, lääkeostot eivät välttämättä ajoitu toimeentulotukikuukausille tai lääkeostoihin ei ole käytettävissä maksusitoumusta lääkkeiden ostohetkellä, jolloin lääkeosto pitäisi ensin maksaa itse. Niillä sairailla pienituloisilla, jotka eivät saa tai hae toimeentulotukea, voi silti esiintyä lääkkeiden ja terveyspalvelujen alikäyttöä vielä enemmän kuin toimeentulotukea saavilla. Aiemman väestökyselytutkimuksen perusteella lääkkeistä, sairaalakäynneistä tai muista hoidoista kustannussyistä tinkineistä $34 \%$ ilmoitti hakeneensa mutta vain $17 \%$ saaneensa toimeentulotukea (35).

Vakioinnissa havaittiin, että maahanmuuttajilla korvausoikeudet ja lääkkeiden käyttö ovat harvinaisempia kuin kantaväestöön kuuluvilla. Tutkimuksen perusteella ei voida päätellä, liittyykö havainto eroihin sairastavuudessa vai lääkkeiden tai etuuksien alikäyttöön. Erityiskorvausoikeuksia voidaan olettaa olevan sitä vähemmän, mitä vähemmän aikaa henkilö on ollut järjestelmän piirissä. Toisaalta puutteellinen kielitaito voi vaikuttaa hoito- ja etuudenhakuprosesseihin. Jatkotutkimuksissa on syytä selvittää, saavatko maahanmuuttajat tarpeeseensa nähden riittävästi sairausvakuutusetuuksia ja hoitoa.

Tutkimuksen vahvuutena on kattava rekisteriaineisto, joka sisältää koko helsinkiläisen aikuisväestön. Keskittyminen Helsinkiin mahdollistaa maahanmuuttajataustan kattavan vakioimisen, sillä lähes puolet Suomen maahanmuuttajista asui tutkimusvuonna Helsingin seudulla (16). 
Tutkimuksen heikkoutena puolestaan on ensinnäkin lyhyt tarkasteluaika (yksi vuosi). Palvelujen käyttöön perustuvan tutkimustiedon (7) perusteella on todennäköistä, että toimeentulotuen saannin kestolla on yhteys lääkkeiden käyttöön ja erityiskorvausoikeuksiin. Toiseksi, vaikka tutkimuksessa pyrittiin vakioimaan aiempaa laajemmin eroja toimeentulotuen saajien ja ei-toimeentulotuen saajien sosioekonomisissa ja demografisissa ominaisuuksissa, jäi tutkimuksen ulkopuolelle edelleen useita sekoittavia tekijöitä, jotka vaikuttavat lääkekorvausoikeuksiin ja lääkkeiden käyttöön. Valtaosa toimeentulotuen saajista on työttömiä tai muuten työmarkkinoiden ulkopuolella olevia, eikä heillä ole mahdollisuutta käyttää työterveyshuollon palveluita. Osa eroista voi johtua työmarkkina-aseman tuottamista eroista palvelujen saatavuudessa. Muita tällaisia tekijöitä ovat koulutukseen, kielitaitoon ja toimintakykyyn liittyvät tekijät, jotka voivat vaikuttaa hoidon saatavuuteen, käyttöön tai hoitomyöntyvyyteen. Kolmanneksi, jokainen toimeentulotukeen oikeutettu ei välttämättä hae tukea (36). Eläkeikäisten pieni osuus toimeentulotuen saajista voi osittain selittyä eläkkeensaajan asumistuen yleistä asumistukea korkeammalla tasolla, mutta taustalla voi olla toimeentulotuen alikäyttöä.

Tutkimuksen tulosten pohjalta voidaan antaa joitain suosituksia. On selvää, että jatkossa on tärkeää varmistaa toimeentulotuen asiakkaiden tarpeellisten lääkkeiden saatavuus. Toimeentulotuen siirron Kelassa aiheuttamat ruuhkat on saatu purettua ja toiminta vakiinnutettua (1). Kelasiirto on jo aiheuttanut toimintatapojen muutoksia lääkkeiden maksamisessa. Kela myöntää toimeentulotuen saajille automaattisesti sähköisen maksusitoumuksen apteekkiin, mikä on lisännyt toimeentulotuen maksusitoumuksella maksettuja lääkeomavastuita (37). Tämä voi vaikuttaa positiivisesti lääkkeiden saatavuuteen, koska maksusitoumusta ei tarvitse erikseen hankkia silloin, kun lääkehoidon tarve on äkillinen. Toi- meentulotuesta maksettavien lääkehoitojen tarpeellisuutta on ryhdytty arvioimaan aiempaa kattavammin, mikä voi vaikuttaa siihen, mitä valmisteita toimeentulotuesta jatkossa maksetaan (38).

Laajemmin tarkasteltaessa tutkimus vahvistaa kuvaa sairauden merkityksestä osana huonoosaisuutta. Jatkotutkimuksissa tulisi pyrkiä löytämään keinoja, joilla toimeentulotukiriippuvuuden syntymistä voitaisiin ehkäistä ennalta varhaisemmilla toimintakyvyn säilyttämiseen tähtäävillä toimilla. Päihde- ja mielenterveysongelmaisten toimeentulotuen pitkäaikaisasiakkaiden on havaittu jäävän usein syrjään sosiaalityöstä (39). Toimeentulotukiuudistuksen yksi tavoite oli, että sosiaalityölle jäisi kunnissa enemmän aikaa (40). Jatkotutkimuksissa tavoitteen toteutumista on syytä seurata. Toimeentulotuen kattavamman tilastoinnin avulla voidaan jatkossa selvittää tarkemmin lääke- ja sairaanhoitomenojen itsenäistä vaikutusta toimeentulotuen tarpeeseen. Tällä on merkitystä ensisijaisten etuuksien riittävyyden arvioinnissa. Alustavien vuoden 2017 tietojen perusteella toimeentulotuesta maksetaan merkittävässä määrin korvausjärjestelmän ulkopuolella olevia lääkkeitä (38). Näiden merkitystä toimeentulotuen tarpeelle on syytä arvioida. Lisäksi tarkentuvia tilastotietoja on syytä hyödyntää mahdollisen korvausoikeuksien alikäytön selvittämiseen.

\section{KIRJOITTAJIEN KONTRIBUUTIOT:}

Kaikki kirjoittajat osallistuivat tutkimuksen suunnitteluun ja toteutukseen, osallistuivat käsikirjoitusversioiden kirjoittamiseen sekä lukivat ja hyväksyivät käsikirjoituksen viimeisimmän version. Ahola muodosti tutkimuksessa käytettävän aineiston. Ahola sekä Lekander tekivät tutkimuksen analyysit. Lekander laati käsikirjoituksen ensimmäisen version osana pro gradu työtään, jota Hiilamo ohjasi. Aaltonen oli päävastuussa julkaistavan käsikirjoitusversion kirjoittamisesta. 
Inequities in the quality and availability of health services may play a role in increasing health inequalities. Social assistance (SA) recipients have worse health and higher use of public health services than non-recipients. This study examines medicine use and entitlements for higher medicine reimbursements among SA recipients $(\mathrm{N}$ $=37,836)$ and non-recipients $(\mathrm{N}=430,997)$ in Helsinki, in 2010. Register data were analysed by using weighting and logistic regression. After adjusting for age, gender, immigration status, income and student status, it was more common for SA recipients to have reimbursement entitlements $(20 \%$ vs. $15 \%)$. They had also more often purchased medicines for psychiatric disorders ( $34 \%$ vs. $14 \%)$, asthmatic diseases ( $11 \%$ vs. $5 \%)$, diabetes $(6 \%$ vs. $3 \%)$ or cardiovascular diseases ( $21 \%$ vs. $13 \%)$. Purchases of psychotropics became more common when the number of months on SA increased. However, entitlements based on psychiatric disorders were most common among those receiving SA for 1-3 months. The association between psychiatric medication (purchase or entitlement) and SA was similar regardless of migration status (odds ratios (OR) for those on SA for 1-3 and 10-12 months (REF: non-SA recipients) native-born 2.8 [95\% CI 2.7-2.9] and 5.3 [5.0-5.5]; OECD-countries 2.4 [1.9-3.2] and 7.8 [6.4-9.5]; post-Soviet states 2.3 [1.8-3.0] and 3.6 [2.9-4.3]; other countries 2.0 [1.6-2.6] and $5.1[4.4-6.0])$. The results are in line with the understanding of illness as one factor in the process of accumulating disadvantage. Health problems should be acknowledged when developing services targeted at SA recipients.

Keywords: medicines, social assistance, health inequalities

Saapunut 21.12.2017

Hyväksytty 21.05.2018

\section{LÄHTEET}

(1) Itkonen, A, Välisalmi, O. Toimeentulotuen siirron ulkoinen arviointi. Loppuraportti. BDO Oy. Luettu 16.10.2017. http://www.kela.fi/ documents/10180/0/kelan+toimeentulon+siirron +ulkoinen+arviointi/62aa22b6-3e4f-4d26-abe8$61 \mathrm{c} 495 \mathrm{cff} 07 \mathrm{a}$

(2) Perustoimeentulotuen siirto Kelaan. Kelan sisäinen arviointi. Helsinki: Kela; 2017. Luettu 16.10.2017. http://www.kela.fi/ documents/10180/3571044/toturaportti0806. pdf/06f4fd6b-50de-4302-b6ea-ac5c2adb0ae9

(3) Ylikännö M, Näätänen AM. Toimeentulotuen Kela-siirto esimerkki tiedon ja poliittisen valmistelun kohtaamattomuudesta. TITA Policy Brief 6/2017. Luettu 20.10.2017. https://blogit. utu.fi/tita/2017/09/11/toimeentulotuen-kelasiirto-esimerkki-tiedon-ja-poliittisen-valmistelunkohtaamattomuudesta/

(4) Martikainen JE, Autti-Rämö I. Lääkkeitä rauhattomille pojille ja masentuneille tytöille. Kirjassa: Hämäläinen U, Kangas O (toim.) Perhepiirissä. Helsinki: Kelan tutkimusosasto; 2010, 216-235. http://hdl.handle. net/10138/17471

(5) Paananen R, Ristikari T, Merikukka M, ym. Lasten ja nuorten hyvinvointi Kansallinen syntymäkohortti 1987 -tutkimusaineiston valossa. Helsinki: Terveyden ja hyvinvoinnin laitos; 2012. http://urn.fi/ URN:ISBN:978-952-245-696-0

(6) Vaalavuo M. Toimeentulotukiasiakkaiden terveyspalveluiden käyttö pääkaupunkiseudulla. Janus 2016;24(3):230-250.

(7) Vaalavuo M. The development of healthcare use among a cohort of Finnish social assistance clients. Testing the social selection hypothesis. Sociology Health Illness 2016;38(8):1272-1286. doi: https://doi.org/10.1111/1467-9566.12458 10.1111/1467-9566.12458

(8) Nyman J, Arffman M, Keskimäki I. Toimeentulotuen asiakkaiden terveyspalvelujen käyttö Helsingissä vuonna 2014. Sosiaalilääk Aikak 2017;54:301-326. https://doi.org/10.23990/sa.67761

(9) Aaltonen S, Berg P, Ikäheimo S. Nuoret luukulla. Kolme näkökulmaa syrjäytymiseen ja nuorten asemaan palvelujärjestelmässä. Helsinki: Julkaisuja 160, Nuorisotutkimusverkosto/ Nuorisotutkimusseura; 2015.

(10) Hannikainen-Ingman K, Kuivalainen S, Sallila S. Toimeentulotuen asiakkaiden elinolot ja hyvinvointi. Kirjassa: Kuivalainen S (toim.) Toimeentulotuki 2010-luvulla. Helsinki: Terveyden ja hyvinvoinnin laitos; 2013, 81-112. http://urn.fi/URN:ISBN:978-952-245-866-7

(11) Kokko S, Virta L, Vehko T. Terveyskeskusten hoitovastuu tyypin 2 diabetesta ja verenpainetautia sairastavista. Suom Lääkäril 2015;44(70):2945-2949. 
(12) Kerätär R, Karjalainen V. Pitkäaikaistyöttömillä on runsaasti hoitamattomia mielenterveyshäiriöitä. Suom Lääkäril 2010;45(65):3683-3689.

(13) Heikkilä M. Köyhyys ja huono-osaisuus hyvinvointivaltiossa. Tutkimus köyhyydestä ja hyvinvoinnin puutteiden kasautumisesta Suomessa. Helsinki: Sosiaalihallitus; 1990.

(14) Tanninen T, Julkunen, I. Elämään säästöliekillä. Tutkimus toimeentulotuen pitkäaikaisista asiakkaista Pohjoismaiden pääkaupungeissa. Helsinki: Sosiaali- ja terveysalan tutkimus- ja kehittämiskeskus; 1993.

(15) Ohrem Naper S. All-cause and cause-specific mortality of social assistance recipients in Norway: A register-based follow-up study. Scand J Public Health 2009;37(8):820-825. doi: $10.1177 / 1403494809347023$ https://doi.org/10.1177/1403494809347023

(16) Tervola J, Verho J. Toimeentulotuki ja maahanmuuttajat Helsingissä. Kirjassa: Ahola E, Hiilamo H (toim.) Köyhyyttä Helsingissä. Toimeentulotuen saajat ja käyttö 2008-2010. Helsinki: Kelan tutkimusosasto; 2013: 71-87. http://hdl.handle.net/10138/38938

(17) Koponen P, Kuusio H, Keskimäki I, ym. Avosairaanhoidon palvelujen käyttö. Kirjassa: Castaneda A, ym. (toim.) Maahanmuuttajien terveys ja hyvinvointi - Tutkimus venäläis-, somalialais- ja kurditaustaisista Suomessa. Helsinki: Raportti 61, Terveyden ja hyvinvoinnin laitos; 2012. http://urn.fi/ URN:ISBN:978-952-245-739-4

(18) Castaneda A, ym. (toim.) Maahanmuuttajien terveys ja hyvinvointi - Tutkimus venäläis-, somalialais- ja kurditaustaisista Suomessa. Helsinki: Raportti 61, Terveyden ja hyvinvoinnin laitos; 2012. http://urn.fi/ URN:ISBN:978-952-245-739-4

(19) Lekander K. Ovatko köyhät kipeitä? Tutkimus toimeentulotuen saajien sairastavuudesta Helsingissä lääkekäytön perusteella. Pro gradu -tutkielma. Helsinki: Helsingin yliopisto; 2016. http://urn.fi/URN:NBN:fi:hulib-201703273586

(20) Ahola E. Yleiskatsaus toimeentulotuesta Helsingissä. Kirjassa: Ahola E, Hiilamo H (toim.) Köyhyyttä Helsingissä. Toimeentulotuen saajat ja käyttö 2008-2010. Helsinki: Kelan tutkimusosasto; 2013, 18-29. http://hdl.handle.net/10138/38938

(21) Toimeentulotukiasiakkaiden sosiaali- ja terveyspalveluiden käyttö. Terveyden ja hyvinvoinnin laitos 2015. Luettu 11.11.2015. https://www.thl.fi/fi/tutkimus-ja-asiantuntijatyo/ hankkeet-ja-ohjelmat/peruspalvelujen-toimivuusvaikuttavuus-ja-kustannukset/toimeentulotuki/ tutkimusteemat/palvelutkaytto

(22) Blomgren J, Aaltonen K, Tervola J, ym. Kelan sairaanhoitokorvaukset tuloryhmittäin. Kenelle korvauksia maksetaan ja kuinka paljon? Helsinki: Kelan tutkimusosasto; 2015. http://hdl. handle.net/10138/154606
(23) Ylikännö M. Nuoret toimeentulotuen saajat Helsingissä. Kirjassa: Ahola E, Hiilamo H (toim.) Köyhyyttä Helsingissä. Toimeentulotuen saajat ja käyttö 2008-2010. Helsinki: Kelan tutkimusosasto; 2013, 54-70. http://hdl.handle.net/10138/38938

(24) Ahola E, Hiilamo H. Keitä olivat laman tuomat uudet toimeentulotukiasiakkaat Helsingissä? Kirjassa: Ahola E, Hiilamo H (toim.) Köyhyyttä Helsingissä. Toimeentulotuen saajat ja käyttö 2008-2010. Helsinki: Kelan tutkimusosasto; 2013, 111-124. http://hdl.handle.net/10138/38938

(25) Sairausvakuutuslaki 21.12.2004/1224. https:// www.finlex.fi/fi/laki/ajantasa/2004/20041224

(26) Valtioneuvoston asetus vaikeiden ja pitkäaikaisten sairauksien lääkehoidon kustannusten korvaamisesta 17.1.2013/25

(27) Terveyspuntari. Kela 2015. Luettu 8.3.2016. http://www.kela.fi/terveyspuntari

(28) THL:n sairastavuusindeksi. Terveyden ja hyvinvoinnin laitos 2015. Luettu 8.3.2016. http://www.terveytemme.fi/ sairastavuusindeksi/2012/notes/notes.htm

(29) Ahola TL, Kantola IM, Puukka P, ym. Positive change in the utilization of antihypertensive and lipid-lowering drugs among adult CHD patients in Finland: results from a large national database between 2000 and 2006. Eur J Prev Cardiol 2010;17(4):477-485. doi: 10.1097/ HJR.0b013e328336a138 https://doi.org/10.1097/HJR.0b013e328336a138

(30) WHO Collaborating Centre for Drug Statistics Methodology. ATC/DDD index. Luettu 20.10.2017. http://www.whocc.no/atcddd/

(31) Suomen virallinen tilasto (SVT): Väestörakenne [verkkojulkaisu]. Helsinki: Tilastokeskus. Luettu 6.3.2018. http://www.stat.fi/til/vaerak/kas.html

(32) Masennus vie yhä harvemman työkyvyttömyyseläkkeelle. Eläketurvakeskus. Tiedote 16.3.2016. Luettu 20.10.2017. http://www.etk.fi/tiedote/masennus-vie-yhaharvemman-tyokyvyttomyyselakkeelle/

(33) Suvisaari J, Perälä J, Viertiö S, ym. Psykoosien esiintyvyys ja alueellinen vaihtelu Suomessa. Suom Lääkäril 2012;67(9):677-683.

(34) Martelin T, Murto J, Pentala O, ym. Terveys, terveyserot ja niiden kehitys. Kirjassa: Vaarama M, Karvonen S, Kestilä L, ym. (toim.) Suomalaisten hyvinvointi 2014. Helsinki: Terveyden ja hyvinvoinnin laitos; 2014: 62-79. http://urn.fi/URN:ISBN:978-952-302-015-3

(35) Aaltonen K, Miettinen J, Airio I, ym. Costrelated barriers to use of health services and prescription medicines in Finland. A crosssectional survey. European Journal of Public Health 2015;25(3):368-372. doi: https://doi.org/10.1093/eurpub/cku176 10.1093/eurpub/cku176

(36) Kuivalainen S. Toimeentulotuen alikäytön laajuus ja merkitys. Yhteiskuntapolitiikka 2007;72(1):49-56. 
(37) Kurko T, Martikainen JE, Rättö H, Aaltonen K. Tyypin 2 diabeteslääkkeiden korvaustasoa alennettiin. Mitä tiedetään vaikutuksista? Kelan tutkimusblogi 20.6.2017. Luettu 19.12.2017. http://blogi.kansanelakelaitos.fi/arkisto/3977

(38) Autti-Rämö I, Kastarinen H, Järvenpää T, ym. Perustoimeentulotuen terveydenhuoltomenot arvioi nyt Kela. Suom Lääkäril 2017;37(72):2022-2024.

(39) Saikku P, Kuivalainen S. Toimeentulotukityö kunnissa. Organisointi, työnjako ja kokemukset. Kirjassa: Kuivalainen S (toim.) Toimeentulotuki 2010-luvulla. Tutkimus toimeentulotuen asiakkuudesta ja myöntämiskäytännöistä. Helsinki: Terveyden ja hyvinvoinnin laitos; 2013. http://urn.fi/URN:ISBN:978-952-245-866-7

(40) Saikkonen P, Ylikännö M. Lisääkö toimeentulotukiuudistus tarpeetonta byrokratiaa? Helsingin Sanomat, mielipide, 23.1.2017.

\section{Katri Aaltonen}

FaT, erikoistutkija

Kela

Tutkimusryhmä, Tieto- ja viestintäyksikkö

KAARLO LEKANDER

VTM, tutkimusharjoittelija (Kela)

Helsingin yliopisto

Valtiotieteellinen tiedekunta, Sosiaalitieteiden laitos

Elina AHOLA

FM

Heikki Hillamo

VTT, FT, professori

Helsingin yliopisto

Valtiotieteellinen tiedekunta, Sosiaalitieteiden laitos 